Florida International University FIU Digital Commons

3-29-2012

\title{
Arthur and Una: Mis-pairings and Delays in 'The Faerie Queene' Book 1
}

Laura E. Creel

Florida International University, lcree001@fiu.edu

DOI: $10.25148 /$ etd.FI12042316

Follow this and additional works at: https://digitalcommons.fiu.edu/etd

\section{Recommended Citation}

Creel, Laura E., "Arthur and Una: Mis-pairings and Delays in 'The Faerie Queene' Book 1" (2012). FIU Electronic Theses and Dissertations. 586.

https://digitalcommons.fiu.edu/etd/586 


\section{FLORIDA INTERNATIONAL UNIVERSITY}

Miami, Florida

\section{ARTHUR AND UNA: MIS-PAIRINGS AND DELAYS IN ‘THE FAERIE QUEENE’ BOOK 1}

A thesis submitted in partial fulfillment of

the requirements for the degree of

MASTER OF ARTS

in

ENGLISH

by

Laura Elizabeth Creel 
To: Dean Kenneth G. Furton

College of Arts and Sciences

This thesis, written by Laura Elizabeth Creel, and entitled Arthur and Una: Mis-pairings and Delays in 'The Faerie Queene' Book 1, having been approved in respect to style and intellectual content, is referred to you for judgment.

We have read this thesis and recommend that it be approved.

Heather Blatt

$\begin{array}{r}\hline \text { Vernon Dickson } \\ \hline \text { James Sutton, Major Professor }\end{array}$

Date of Defense: March 29, 2012

The thesis of Laura Elizabeth Creel is approved.

Dean Kenneth G. Furton
College of Arts and Sciences

Dean Lakshmi N. Reddi University Graduate School

Florida International University, 2012 
ABSTRACT OF THE THESIS

ARTHUR AND UNA: MIS-PAIRINGS AND DELAYS IN 'THE FAERIE QUEENE' BOOK 1

\author{
by \\ Laura Elizabeth Creel \\ Florida International University, 2012 \\ Miami, Florida \\ Professor James Sutton, Major Professor
}

The purpose of this project centered around Spenser's representations of the mythic Arthur. Using a New Historicist approach, I situated Arthur within a late Elizabethan religious context, a context filled with images of and discourse about Apocalypse and the return of Christ.

This context makes its way into The Faerie Queene through Arthur. Seeking his bride, Gloriana, he stands for the Christ as figured by St. John's Revelation, the Christ which will return at the end of time to unite his own Bride, the Church. This marriageand others in the poem-is always deferred, however. This deferral of marriages reflects the failed hopes of Protestants like Spenser for immediate Apocalypse. I concluded that these failed hopes permeate Spenser's text both through delayed marriages and through an ever-present undercurrent of expectations for consummation not in the temporal present, but rather in some unforeseeable, inaccessible future. 


\section{TABLE OF CONTENTS}

CHAPTER

PAGE

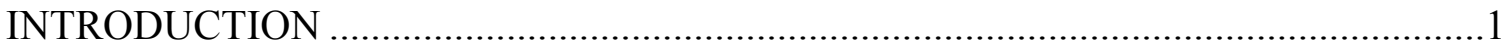

ARTHUR, UNA, AND MARRIAGE …………......................................................

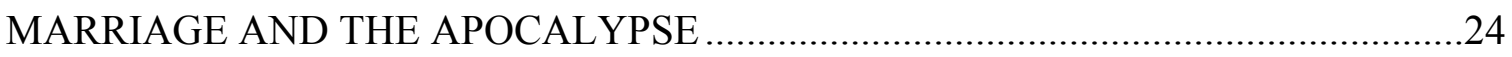

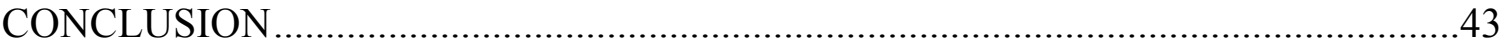

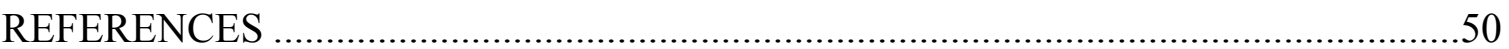




\section{INTRODUCTION}

In 1589, Edmund Spenser wrote a letter to Sir Walter Raleigh to be published alongside his epic poem, The Faerie Queene. He entitles, or prefaces, it: "A Letter of the Authors expounding his whole intention in the course of this worke: which for that it giueth great light to the Reader, for the better vnderstanding is hereunto annexed,"1 and indeed, he continues to provide detailed explanations for the allegorical significance of the poem, the twenty-four Books the poem was to contain (had not Spenser's untimely death interfered), as well as the individual virtue that each would focus on, which female characters would be modeled after Queen Elizabeth, and what social effects he hoped his work would have.

His "intention" for the social impact of the entire poem was "to fashion a gentleman or noble person in vertuous and gentle discipline."2 In order to do this then, he establishes Prince Arthur as the model around which the poem would revolve. According to the letter, the Prince was to act as the binding agent for all the Books, exemplifying magnanimity, or what the poet calls the Aristotelian conflation/culmination of the "twelue priuate morall vertues." 3 He is envisioned, at least according to Spenser's explanation to Raleigh, as the perfect knight, the ideal player in a courtly romance, the standard of goodness to which all other knights aspire; he is "excellency" itself. ${ }^{4}$

\footnotetext{
${ }^{1}$ Edmund Spenser, The Faerie Queene, ed. A.C. Hamilton et al, $2^{\text {nd }}$ ed. (Harlow, England: Pearson Education, 2007), page 714, title.

2 Ibid., 714, lines 7-8.

${ }^{3}$ Ibid., 715.19.

${ }^{4}$ Ibid., 715.11 .
} 
Spenser's choice to name Arthur as his model carries with it religious resonances that A.C. Hamilton identifies when he notes that Caxton wrote of Arthur as "the moost renomed Crysten kyng. " ${ }^{5}$ For at least a century before Spenser was writing, there existed a tendency to associate Arthur with a type of standard for Christianity. When paired with the Arthur who exemplifies Aristotelian virtues, a dichotomy of classical and Christian allegory, imagery, and allusion arises which persists beyond the Letter and into the text itself.

In this thesis, I will argue that the Prince Arthur character found in Book I is unmistakably the Christ-figure of the text. He represents Christ in the Faery Lond world, and replicates and replays the story of the Christian Passion. I draw a distinction between Book I and Books II-VI because, as I will show, Arthur does not retain the position of Christ-figure in those latter Books. Thus, I focus my work primarily on the Arthur of Book I, where he is most closely identified with Christ. Indeed, the Christological parallels are so strong in this first Book that many critics have been tempted to continue reading Arthur as a Christ-figure throughout the whole of The Faerie Queene. D. Douglas Waters writes of him specifically as "Christian magnanimity," and as the "minister of grace" ${ }^{, 7}$ who is the only one that can save Redcrosse from Orgoglio. ${ }^{8}$ Michael Leslie additionally writes of Arthur's "ultimate invulnerability... [which is]

\footnotetext{
${ }^{5}$ Qtd in A.C. Hamilton, ed., The Faerie Queene (Harlow, England: Pearson Education, 2007), 715.11 note.

${ }^{6}$ D. Douglas Waters, "Prince Arthur as Christian Magnanimity in Book One of The Faerie Queene," Studies in English Literature, 1500-1900 9, no.1 (Winter 1969):53.

${ }^{7}$ Ibid., 58.

${ }^{8}$ Ibid., 60.
} 
pervasive in all of the Prince's adventures." ${ }^{9}$ Susanne L. Wofford writes of the classical and Christian dichotomy both in the Letter and in the poem, noting: " 'magnificence' recedes from view in the course of the narrative, since Spenser seems to identify Arthur at the moment of his entry with 'heavenly grace'.,"10

Indeed, I agree with these readings, as long as they are centered around Book I, but for the most part, such studies do not examine the implications of his later behavior in the poem, and the effect of it on the reading of the allegory as a whole. Many later critics have often followed the same pattern of attributing to Arthur the status of most virtuous knight. While Christopher Bond tangentially mentions some of the problematics of Arthur's moral character in a footnote, he still claims that the knight "seems to have attained in large part the qualities that the lesser heroes struggle so hard to learn," that he is a "less fallible hero." ${ }^{11}$ My reading, however, reaches the conclusion that the Arthur found in the Letter and Book I slowly begins to unravel as the poem progresses.

In the first of the six Books of The Faerie Queene that Spenser actually completed before his death, the Book of Holinesse, Arthur makes a grand entrance to rescue the main characters, an unmistakable reference to the saving and irresistible grace of Christ to which Spenser was so committed. By the second Book, though, Arthur is clearly

\footnotetext{
${ }^{9}$ Michael Leslie, Spenser's Fierce Warres and Faithfull Loves': Martial and chivalric Symbolism in The Faerie Queene, (Cambridge: D.S. Brewer, 1983), 49; italics mine.

${ }^{10}$ Suzanne L. Wofford, "The Enfolding Dragon: Arthur and the Moral Economy of The Faerie Queene," in Edmund Spenser: Essays on Culture and Allegory, ed. Jennifer Klein Morrison and Matthew Greenfield (Aldershot, England: Ashgate, 2000), 154.

${ }^{11}$ Christopher Bond, "The 'Legend of Holinesse' and the Fall of Man: Spenser's Faerie Queene 1 as Milton's Original for Paradise Lost 9 and 10," in Uncircumscribed Mind: Reading Milton Deeply, ed. and introd. Charles W. Durham and Kristen A. Pruitt (Selinsgrove, PA: Susquehanna UP, 2008), 207.
} 
shown to be subject to physical, emotional, and mental weakness. He ceases to reflect Spenser's characterization of magnanimity set before the reader of the Letter to Raleigh and of the first Book. Although I do not dwell extensively on this process of unraveling, I do show how the text of Book I sets the stage for and effects it. Several key episodes are explored in the attempt to understand how and why this change occurs.

The Arthur of the first Book of The Faerie Queene stands out as the poem's singular Christ figure, whose story very closely parallels the narrative of the Biblical Passion and Resurrection. In this next chapter, I first analyze his role as Christ within Faery Lond, within the scope of Book I. Spenser carefully structures Arthur's actions and movement so that they unmistakably recall the death and resurrection of Christ and the salvation provided through it. Having Arthur fill the role of Christ figure within the first Book shapes the way we understand him, especially when he ceases to fill this role later in the poem, as I will argue that he does.

I also work to show Una as the character that represents the reformed Protestant Church. This reading is supported by some of the oldest critics of the poem, but I extend this interpretation by reading her as a being which exists both within, and without, the time and space of Faery Lond. This dual existence separates her from all the other characters in the poem, except for the Arthur of Book I; because they are Heavenly beings, both Una and Arthur are possessed of a state that allows them to both participate and not participate in linear time.

As this key figure and the possessor of all virtues, Arthur is additionally (in this Letter) the only character worthy of the love and marriage of Gloriana, the alwayspervasive but never-present representation of Elizabeth. But perhaps the most intriguing 
aspect of this "real" Arthur of the Letter is that his marriage to Gloriana never takes place. He is on quest to find her (or so he tells the several women he meets along the way) but the final consummation of their marriage is perpetually deferred. Arthur is always delayed from achieving this teleological aim, a delay which is paradigmatic of and causal to the deferral of several other important marriages in the text. I argue that this deferral is representative of the deferral of Apocalypse, the True Marriage between Christ and his Church that Spenser never saw fulfilled. This mirroring sets the poem firmly within the late Elizabethan religious moment, and causes it to embody the failed hopes of his contemporaries and of Spenser himself.

Reading Arthur and Una allegorically allows us to make some sense of the strange and abrupt ending of Book I, in which a marriage almost occurs between Una and Redcrosse, but is suddenly curtailed. I link the delay of this marriage, and indeed the delay of many other marriages in this text, to the delay of apocalypse. Because Biblical apocalypse is partly signaled by a Marriage, a delay of marriage within the text symbolizes a delay in apocalypse. I argue that these deferrals cause the moral decay of Arthur which occurs in the latter Books of The Faerie Queene. Whereas in Book I he resembles almost identically the Biblical Christ, the signs of weakness and imperfection that Arthur later begins to manifest are the result of the failed marriage and the failed apocalypse at the end of this first Book.

The most important Biblical allusion that I identify in this thesis, and arguably the most important in Book I of The Faerie Queene, is the joining of the Church to Christ which occurs in the nineteenth chapter of St. John's Revelation. This joining is represented symbolically both in Revelation and in the poem as a marriage, and indeed 
the most important marriage of all, for it signals the ending of the earthly, sinful world and the beginning of a new existence under Christ. As such, marriage is symbolic of Apocalypse, of the End.

The account of this marriage ceremony in Revelation is almost played out through the characters of Redcrosse and Una, but ultimately fails. In fact, after this failed union, all of the major promised/prophesied weddings in the poem fail to take place. They are perpetually deferred to another time in the vague future with the vague expectation of their someday fulfillment, but they never actually take place within the text as we have it. Even the most important union, that of Arthur and Gloriana as detailed in the Letter, never achieves its final goal of consummation. Arthur is never able to find this Faery Queene, although it seems that she makes herself readily available to the other characters who seek her. ${ }^{12}$

This forestalling of marriage corresponds, I believe, with the forestalling of apocalypse both in Spenser's world and in Faery Lond. John Watkins writes of religious figures such as John Foxe who attributed "an apocalyptic agency to Elizabeth during her reign's opening decades." ${ }^{\prime 13}$ Although differences existed about what exactly the End would look like—whether it would be pre-, post-, or a-millennial—-many Reformation leaders believed that the establishment of Elizabeth's throne would in some way speed up the process to such an End, and usher in a new, cleansed Beginning. ${ }^{14}$ There were many

\footnotetext{
${ }^{12}$ See page 38 herein for further discussion.

${ }^{13}$ John Watkins, “ 'And yet the end was not': Apocalyptic Deferral and Spenser's Literary Afterlife," in Worldmaking Spenser: Explorations in the Early Modern Age, ed. Patrick Cheney and Lauren Silberman (Lexington: The UP of Kentucky, 2000), 159.

${ }^{14}$ Ibid., 158-159.
} 
disappointed hopes when this did not happen; one of those disappointed hopes was Spenser's and was accompanied by what Watkins calls "the embarrassment of temporal continuity."

To clarify “apocalypse," Andrew Escobedo has identified four phases of apocalyptic thinking in the early modern period: 1) Marian apocalyptic, 2) earlyElizabethan apocalyptic, 3) post-Armada apocalyptic, and 4) Civil War apocalyptic. ${ }^{16}$ I am not concerned, as other critics are, in determining exactly which texts fit into which of these categories, or in determining when apocalyptic thought changed. I am also not concerned with whether texts are pre- or post- or a-millennial. These categories are very useful for some work, but for this project in particular I use "apocalypse" very loosely, simply because my argument does not require such a focused definition. I am concerned primarily with apocalypse as an Ending of time, one which is accompanied by the marriage supper of the Lamb to his Bride the Church. Whether this supper happens on Earth or elsewhere is out of the scope both of my knowledge and of this paper.

In the next chapter, I read Arthur and Una strictly as allegorical figures that correspond to Biblical counterpoints. I am aware that readings like this have become unfashionable of late, in our current period of poststructural criticism. It is not in vogue to read like this now, for interpreting allegory means finding a definite, objective, Real referent for the allegorical symbol used in the text. To say that Arthur is Christ, for example, is essentially to posit a Truth. However, the point of the allegory as it is written

\footnotetext{
${ }^{15}$ Ibid., 159.

${ }^{16}$ Andrew Escobedo, Nationalism and Historical Loss in Renaissance England: Foxe, Dee, Spenser, Milton. (Ithaca, NY: Cornell UP, 2004), 83.
} 
by Spenser is to give "great light to the Reader, ${ }^{17}$ and so in interpreting this allegory I am doing the work as laid out by Spenser himself. The poem is most fundamentally an allegorical one, whatever else it is in addition, and it is often the case that to speak of Spenser is to speak of allegory. We cannot, and indeed should not, attempt to get away from the allegorical placement that Spenser has set up.

A final note before I begin the body of the work: much of the work done here is influenced by Biblical texts, on which I rely heavily. Because of the allusive nature of the poem, I believe it impossible to read Book I critically without at least gesturing to the Christian allegory which permeates the text, and much of my argument is built on such readings of Scripture. Darryl J. Gless cautions modern readers against relying on simple, anachronistic Biblical interpretations, ${ }^{18}$ and it must be acknowledged that it is impossible for the modern scholar to ever access wholly the religious culture and beliefs of the early moderns, and thus to ever fully replicate their readings. Although scholars face this problem in trying to perform any sort of reading, whether literary or otherwise, I believe I can still do the best, most responsible reading possible if I use the materials that Spenser and his contemporaries used. I have therefore chosen the Geneva Bible, with its telling glosses, as the standard translation in this thesis unless otherwise noted, following the suggestion by Carol V. Kaske of its importance to Spenser. ${ }^{19}$

\footnotetext{
${ }^{17}$ Spenser, 714 title.

${ }^{18}$ Darryl J. Gless, Interpretation and theology in Spenser (Cambridge: Cambridge UP, 1994), 27.

${ }^{19}$ Carol V. Kaske, ed. with intro., The Faerie Queene Book I (Indianapolis: Hackett Publishing, 2006), xii.
} 


\section{ARTHUR, UNA, AND MARRIAGE}

\section{The Arthur-Christ}

Prince Arthur first appears seven cantos into Book I, when he chances upon Una in the forest. After a description of his armor so lengthy it befits the epic hero, he opens a conversation with her, probing to discover the cause of her "secret sorrow." 20 After some time, he finally persuades her to reveal it, and swears an oath to save the captive Redcrosse:

"Certes, Madame, ye haue great cause of plaint,

That the stoutest heart, I weene, could cause to quake.

But be of cheare, and comfort to you take:

For till I haue acquitt your captiue knight, Assure your selfe, I will you not forsake."

His chearefull words reviu'd her chearelesse spright... . [The Faerie Queene (FQ) I.vii 52.3-8].

It is this language that first links him to Christ, for it recalls the language used by Christ at the Last Supper. For example, before he is captured and killed, Jesus speaks to his disciples: "These things haue I spoken vnto you, yt in me ye might haue peace: in the worlde ye shal haue affliction, but be of good comfort: I haue ouercome the worlde."21 Arthur's "chearefull words" that urge "comfort" for Una mimic the self-assured words of Christ that are told the disciples before he goes to his death. He is able to speak in the

\footnotetext{
${ }^{20}$ Spenser, The Faerie Queene, Book I, canto 7, stanza 38, line 4; hereafter cited in the text; italics mine.

${ }^{21}$ The Geneva Bible, book John, chapter 16, verse 33; hereafter cited in the text.
} 
present of already having overcome the world, for his status as both God and man allows him to step outside of time constraints into the future.

The words of Arthur (and Christ) additionally recall Hebrews 13.5-6: "Let your conuersation be without couetousness, and be content with those things that ye haue: for he hathe said, I will not faile thee, nether forsake thee: So that we may boldely say, The Lord is mine helper, nether wil I feare what man can do vnto me.” Because Hebrews was written after the Gospels, Arthur-Christ looks forward beyond the positioning of the Last Supper. This text also contains an allusion that looks back to the past. The Geneva gloss notes that the "he hathe said" refers to the Old Testament passage, Joshua 1.9, in which God speaks to the Israelites: "Haue not I commanded thee, saying, Be strong and of a good courage, feare not nor be discouraged? for I the Lord thy God wilbe with thee, whethersoever thou goest."

These scriptural allusions have more important implications than simple references used to strengthen allegorical connections; they speak directly to issues of time and space. It seems that Arthur is possessed of a dual existence, much like that of Christ. Orthodox Christian belief holds that Jesus existed in his time on Earth as fully God and fully man, and so dwelt both in and out of time miraculously and simultaneously. When Arthur imitates the words of Christ at the Last Supper, and joins them with the verse in Hebrews (which is, in turn, the verse in Joshua), he links past, present, and future together. He eliminates the distinctions of time by combining all of these moments into one, and so temporarily steps outside the constraints of time and space imposed on him and on Faerie Lond. In stepping outside of time he makes himself more like the 
everlasting divinity, who is "the foundation of the Church for euer," as the gloss for Hebrews 13.5 says, and thus makes himself the mouthpiece for Christ.

Arthur's words also exist within the bounded present of Faery Lond. His words become a signal of the battle he will fight, in real time, with Orgoglio. In telling Una that he will absolutely and without doubt rescue Redcrosse, the lost sinner, he parallels himself with Christ telling his disciples of his impending death and future victory over sin and death. He, like Christ, knows of the battle to come, but also recognizes and acknowledges the final victory over Orgoglio. As Arthur speaks to Una, to the One Church, before his fight with Orgoglio, so Christ spoke before his death to the disciples upon whom the Christian Church would later be built.

That Arthur parallels himself with and imitates a Christ who has not yet died is significant, for it means that the Prince, when first entering the text, has not yet experienced his allegorical counterpart to Christ's crucifixion. This counterpoint develops into the fight with Orgoglio. What we have, then, is a Crucifixion story in miniature within the scope of the Book of Holinesse; we see an entire version of the Passion through Arthur. This provides an explanation for the continued failures of Redcrosse: he cannot be rescued from his sin unless there is a rescuer, and that rescuer is Arthur, through whose victory the salvation of Redcrosse can finally be achieved after eight cantos.

The fight for the salvation of Redcrosse, though, is not an easy one, and although it strengthens the parallels between Arthur and Christ, it introduces a problem for critics like Darryl Gless, who reads the fight with Orgoglio as one of Arthur's failures, saying that Arthur "falls before Orgoglio, in a peripeteia which should discourage readers 
growing confident that this hero 'stands for' grace or stands as a 'Christ figure' in any simple and consistent way." ${ }^{22}$ Gless refers primarily to the blow dealt Arthur by Orgoglio: "That stroke vpon his shield so heauie lites, / That to the ground it doubleth him [Arthur] full low: / What mortall wight could euer beare so monstrous blow?" (FQ I.viii 18.7-9). This blow causes Arthur to fall to the ground and allows for a moment of uncertainty in which Orgoglio has the chance to kill Arthur. Arthur is not simply a "mortall wight," however. Gless seems to ignore both this and the next stanza, which informs the reader that the veil covering the blinding whiteness of the knight's shield is loosened in the fall. Because the giant cannot withstand the power that the shield possesses, Arthur is given the chance to take back control over the battle. He seizes his chance, cuts off Orgoglio's leg, and while the giant is down, beheads him. Thus he triumphs over the evil of the giant.

While I agree with Gless that Arthur "[only] intermittently conforms to the image of Christ, ${ }^{, 23}$ I believe that in this particular battle, and indeed this particular Book as a whole, Arthur's fall before Orgoglio makes him more than ever a Christ figure, because this is an obvious dramatization of the crucifixion scene. Arthur's readiness to admit that "to shonne so hideous might" as Orgoglio was "ne shame" ( $F Q$ I.viii 8.1) is not weakness on the part of the knight; instead, it corresponds to Christ's shunning of the hideous might of crucifixion in his prayer in Gethsemane. As noted before, they both understand when they speak to their respective Churches that the battles they will face are hideous.

\footnotetext{
${ }^{22}$ Gless, Interpretation and theology, 137

${ }^{23}$ Ibid., 135.
} 
And while Gless discusses Orgoglio's “monstrous blow" (I.viii 18.9) as evidence of "Arthur's fall,,"24 I would qualify it as the instant in which the Christ-man experiences the death of crucifixion, in which he is momentarily defeated by the great evil of death and sin, in order that he may be resurrected. His fall indeed cannot be borne by "mortall wight." He falls, succumbs to the blow, just as Christ did to death. But this fall also "Did loose his vele by chaunce" (19.2), which allows for a miraculous turn that brings resurrection. Had not a miracle occurred, Christ would have stayed dead, and Arthur would have been finished off by Orgoglio. But something happens which denies death its due.

If we read Arthur's "fall” as parallel to Christ's death, then Gless is correct in asserting that when he rises, Arthur's "true strength" (137) is released, and he can overcome his enemy. His "true strength," though, is not released in the way that Gless maintains. The moment of peripeteia comes not when Arthur falls to Orgoglio's blow, but rather when he rises again after it. It is the eucatastrophe of Tolkien, the " 'turn'... [which in] its fairy-tale- or otherworld- setting,... is a sudden and miraculous grace: never to be counted on to recur." ${ }^{25}$ Tolkien discusses, in his now-famous Andrew Lang Lecture in 1938 for the University of St. Andrews, his theory of the eucatastrophe in art and the joy it inspires in readers, saying that the "turn"

looks forward (or backward: the direction in this regard is unimportant) to the Great Eucatastrophe. The Christian joy, the Gloria, is of the same

\footnotetext{
${ }^{24}$ Ibid., 137.

25 J.R.R. Tolkien, "On Fairy-Stories," in The Tolkien Reader, introd. Peter S. Beagle. (New York: Ballentine Books, 1966), 86.
} 
kind... but this story [the Gloria] is supreme; and it is true. Art has been verified. God is the Lord, of angels, and of men- and of elves. Legend and History have met and fused. ${ }^{26}$

The implications of reading the crucifixion and resurrection of the Christ-Arthur into the eighth canto of Book I are several. Tolkien's ideas on the eucatastrophe in fairy stories are easily transferrable to Spenser's work in this particular passage. The peripeteia of Gless certainly occurs, but in this reading it occurs at a different moment in the story's chronology. If we follow Tolkien's theory in asserting that these "turns" mirror the Christ story, it is powerful and theologically significant that Spenser weaves into his work a complete mirroring of the Passion and Resurrection. It is perfectly within reason to read Arthur as the Christ figure, for his narrative is the crucifixion narrative.

Almost more significant, I think, than the weaving of the Passion narrative into the poetic one is the quality of being that Arthur shares with Christ. Both exist dually, uniquely, and simultaneously within and without time, for Arthur is Rex quondam Rexque futurus just as surely as Christ is "the Lambe, which was slaine from the beginning of the worlde" (Revelation 13.8). Both have lived in the world, in time-whether Earth or Faerie - and both live eternally out of the world where their return into our time is endlessly displaced and deferred to some vague, Other time far in the Future. Like the reader of the Bible, the reader of The Faerie Queene is separated from the Christ-figure by the text's prophesy of death even before he reads the character himself. Before Arthur acts or says one word in the narrative, we learn that after his death the Faery Queene brings his armor to Faerie Lond:

${ }^{26}$ Ibid., 89. 
Both shield, and sword, and armour all he [Merlin] wrought

For this young Prince, when first to armes he fell,

But when he dyde,the Faery Queene it brought

To Faerie lond, where yet it may be seene, if sought. (I.vii 36.6-9).

Understanding this armor is the key to understanding Arthur's purpose: in reading it as a visual representation of his dual state of being, his positioning as Christ becomes virtually indisputable and the deferred return, the deferred Apocalypse, becomes even more prominent, especially in the moment in which the veil falls off of Arthur's shield. It is the one moment in the text where Arthur reveals himself in these two states simultaneously. The light of the shield recalls the light of Christ as he is revealed to John in the first chapter of Revelation. In that passage, the reader meets the risen Christ, whose head and hair is purest white, and whose eyes "were as a flame of fyre" (1.14). The light also draws Arthur into the passage where Christ announces himself as the "the beginning and the ending... Which is, and Which was, and Which is to come" (1.8). The light that Arthur possesses in his shield is the same light of the Christ who is, who has being in all states of time and being outside of time. ${ }^{27}$

\footnotetext{
${ }^{27}$ In Ephesians, Paul exhorts Christians to put on "the whole armour of God" (6.13). This armour, which the Geneva gloss calls "Christian armour," consists of belt, breastplate, shoes, shield, helmet, and sword. Most importantly, or "above all," (16) is the shield of faith with which the "fyrie dartes of the wicked" can be put out (16). It seems that, at least in the case of the battle with Orgoglio, Arthur's shield is the most important piece of his armor as well. It links him once again to Christ, for the light that the shield possesses is reminiscent of the same Light of the World that Christ calls himself in John 9.5. This is the same light that "shineth in ye darkenes," the same light that "the darkenes comprehended... not" (John 1.5).

Arthur's shield is particularly apt to shine in the darkness of his battle with Orgoglio because of the reflectiveness characteristic of its diamond make. It is "perfect pure and cleene," (FQ I.vii 33.5) and is unconquerable because it is hewn from "Adamant rocke" (7). The purity of the shield mimics Arthur's own purity; it is a purity so powerful that it conquers sin, that it shines out in darkness. Because the light from the shield, the Light of the World blinds Orgoglio, Arthur is able to triumph over the giant and show himself possessor of this Christ-like light.
} 
For the oft-discussed passage regarding Arthur's helmet, critics have offered various readings. Suzanne Wofford confronts Michael Leslie's interpretation of the dragon on the helmet as a domesticated one, pointing to textual evidence that links the dragon on the helmet to the earlier description of Errour. While Wofford weaves political interpretations into theories of typology and draws interesting conclusions about Arthur as one who internalizes the strength of the still-alive dragon to become "the dragon of his nation, ${ }^{, 28}$ she insists that the dragon figure retains power in a way that I do not believe the text warrants. For though the dragon's head is "dreadfull" (I.vii 32.5) and his mouth "flaming" (7), it is still locked into the metal of the helmet. It only "seem[s]" to throw sparks (6). The monstrous form of the dragon is intended to frighten, but however frightening it may be, it is still frozen. It is a piece of art, as Wofford rightly notes in designating the stanza as ekphrasis. ${ }^{29}$

Wofford compares Arthur's dragon to the apocalyptic dragon of Revelation, ${ }^{30}$ while Michael Leslie and Kathleen Williams compare it to the dragon Redcrosse slays at the end of Book I. ${ }^{31}$ A.C. Hamilton makes a good case for the dragon of Revelation finding its representation in Redcrosse's dragon, and I need not restate the text's allusions

\footnotetext{
${ }^{28}$ Wofford, "The Enfolding Dragon," 154.

${ }^{29}$ Ibid., 140. Significantly, the only other character in Book I who shares with Arthur the quality of a dual existence (Una), is also frozen into art. I discuss later this freezing in time and art that occurs as a woodcut at the end of Bale's The Image of Both Churches.

${ }^{30}$ Ibid., 163.

${ }^{31}$ Leslie, "Fierce Warres, "53.
} 
to the biblical dragon. ${ }^{32}$ I take it under assumption that these dragons are the same. I do, however, go further than Leslie and Williams in submitting that Arthur's and Redcrosse's dragons should be compared, because they are the very same dragon, albeit one that appears in different states of being at different times.

The descriptions of The Faerie Queene's dragons are too similar to be ignored. They have the same huge wings, as big as "sayles" (I.xi 10.2) that can spread "ouer all" (vii 31.4), the same "flaming mouth" (vii 31.7) sends forth "huge flames" (xi 44.3). Both have very long tails (vii 31.9; xi 11.1-2). Arthur's dragon is "enfold[ed]" on his helmet (vii 31.3) and Redcrosse's rolls itself up "in hundred foldes” (xi 11.1). Most significantly, I think, even the same "couched" is used to describe the dragon's position on the ground and in the helmet (xi 9.2; vii 31.6). The dragons are the same, except that one is bound and the other is not.

This difference in state of being makes sense, however, when Arthur is read as Christ. For if Bauckham is correct in reading the dragon as evil, ${ }^{33}$ Arthur-Christ defeats it with his crucifixion. According to orthodox Christian teaching, sin, death, and evil were defeated, but not defeated finally with the death of Christ. While the dragon does retain a small amount of power with its frightening appearance, it is a power that is constrained and bound by the Arthur-Christ. As art, the helmet serves as a visual reminder of evil ever-present in the world of Faerie Lond. It is not erased, not abolished; it still exists, but it is sealed, kept in check and restrained by the armor that Arthur wears. That he is allowed to put on this armor signifies his power over the dragon. Because Arthur exists

\footnotetext{
${ }^{32}$ See Hamilton, I.xi 9-11 note.

${ }^{33}$ Richard Bauckham, The theology of the Book of Revelation, (Cambridge: Cambridge UP, 1993), 90.
} 
dually, he can have power over this evil, even while it still exists. The dragon belongs with Arthur and Una as a being existing simultaneously in two states announces Arthur as Christ, as the defeater of Evil, before Arthur even speaks. A dragon or an evil that is both alive and not alive is particularly apt for Arthur to be wearing, for he himself is both alive and dead in Faerie Lond, as stanza 36 reveals before Arthur even speaks his first words. The helmet is also yet another reminder of a delayed apocalypse, of an end that has occurred, but only outside of time. Within the time and space of Faery Lond, sin and evil still exist.

Although this sin and evil still exist, though, Faery Lond has its rescuer, at least in Book I. Arthur, here, becomes the Salvation, the Light, for the inhabitants of that place and saves them from evil that they cannot defeat on their own. His narrative is that of the Christ story and his armor is representative of this narrative. Spenser crafts Arthur's character such that it also mirrors the temporal-spatial being of Christ and in doing so, Arthur becomes the once and forever Savior of Faery Lond, willing to risk his own life for that of his friends.

\section{Una as the Church}

Una, too, fills an allegorical place in this poem, and her marriage ceremony to Redcrosse recalls additional Biblical parallels, as well as the structure of Tolkien's eucatastrophe. Redcrosse, once almost dead, has returned to life, and the long-awaited marriage is imminent. This is a direct reference to St. John's description in Revelation 19 of the marriage supper of the Lamb, of Christ, to his wife, the true Church: 
And I heard like a voyce of a great multitude, and as the voyce of manie waters, and as the voyce of strong thondrings, saying, Hallelu-iah: for our Lord God almightie hathe reigned. Let vs be glad and reioyce, and giue glorie to him: for the marriage of the Lamb is come, and his wife hathe made herself readie. And to her was granted, that she shulde be araied with pure fyne linen and shining. for the fine linen is the righteousnes of Sanctes. Then he said vnto me, Write, Blessed are they which are called vnto the Lambes supper.... (6-9a).

I take special note of the attire of the bride: she wears pure, fine linen that shines brightly. This attire is also the attire of Una, which links her to the true Church. As mentioned briefly before, reading her as the Church has been supported by a long line of interpreters and critics as far back as John Dixon and his earliest extant annotations of the poem in $1597 .{ }^{34}$ I take this standard interpretation of Una as representative of the Protestant Church, the true Church of Christ, which has undergone persecution during its own Babylonian-like captivity. In this interpretation, her white garments link her especially to the above-quoted passage from Revelation. In preparing for her marriage supper to the Redcrosse Knight, she

... had layd her mournefull stole aside,

And widow-like sad wimple throwne away, Wherewith her heauenly beautie she did hide, Whiles on her wearie iourney she did ride;

\footnotetext{
34 John N. King, Spenser's Poetry and the Reformation Tradition, (Princeton: Princeton UP, 1990), 72.
} 
And on her now a garment she did weare,

All lilly white, withoutten spot, or pride... ( $F Q$ I.xii 22.2-7).

In his notes to this stanza, A.C. Hamilton makes the connection between the Biblical passage and Una's "fine white linen" clothing ${ }^{35}$. The dark cloak she wore throughout Book I is shed here in expectation of her wedding supper to the Lamb. She can only wear the shining clothes to her wedding supper, which in turn can take place only after Satan has been defeated, only at the End of time, and that end-of-time-moment is signaled by her attire. This is the finale; Redcrosse has been redeemed, the dragon slain, and the Edenic, timeless kingdom restored. Una's "lilly white" clothes take the Church out of the temporal-spatial Faery Lond, and put her into an-Other, Heavenly place, one in which the Church is redeemed. It is a Church not marred with sinners, but renewed with saints, one spotless and "readie" to be brought into final consummation with Christ.

In fact, Una has been the redeemed Church all along during her time in Faery Lond, even with her identity concealed. Her clothes are whiter than the white ass that she rides (I.1 4.1-3), but they are covered. While in the terrestrial world of Faery Lond, she cannot openly wear the celestial "lilly white" garments of her marriage. And because of this, she only exists partly within the space and time of this narrative. While she is in Faery Lond, she chases after the chief sinner, Redcrosse. This is the vision of the Church which seeks to save the lost on a temporally bound Earth. It is Una "on her wearie iourney" (I.xii 22.5). The other part of her, though, dwells in eternity, where the Church is always-already redeemed and comprised of redeemed saints.

\footnotetext{
${ }^{35}$ Hamilton, The Faerie Queene, I.xii 22.2-7 note.
} 
The idea of the Church existing dually in and out of time and space is not a Spenserian invention. It had previously been represented as such both textually and graphically in John Bale's The Image of Both Churches. In his commentary of Tyndale's translation, Bale figures the Woman Clothed with the Sun in Revelation 12 not as the Virgin Mary (as previous interpreters had), but as the true Protestant church. The woodcut at the end of the work contrasts the true with the false church, and the Woman pictured too is with child. The Tyndale text is as follows: "And there appeared a great wonder in heaven. A woman clothed with the sun, and the moon under her feet, and upon her head, a crown of twelve stars. And she was with child, and cried, travailing in birth, pained, ready to be delivered" (Revelation 12.1-2). Bale glosses the woman "travailing in birth" as representative of the history of the Church through time, through the temporal lives of Adam and Eve and the patriarchs, saying: "so waxed the woman bigger and bigger, till the fullness of her time was come that she should be delivered. Which was such time as Christ appeared to the world, taught, and was conversant here among men." ${ }^{36}$ So, in one part, the Woman is delivered of her child the moment that Christ bisected time to enter into our world. Bale also says, though, that "this course have she kept ever since, and shall do to the latter day in them that believe.... She travaileth evermore a new like as did Paul, till Christ be fashioned in her Christian members."37 The Woman is simultaneously delivered and not delivered, depending not on where she is, but when she is.

\footnotetext{
${ }^{36}$ Qtd. in John N. King, ed., Voices Of The English Reformation: A Sourcebook (Philadelphia: U of Pennsylvania P, 2004), 24.

${ }^{37}$ Ibid., 24.
} 
Similarly, while Una's white clothes are covered, she is simultaneously redeemed and not redeemed. This duality of existence lasts from the beginning of the poem until the twelfth canto. Gless talks about the Woman's exile in the desert, and writes that it is a "sanctifying exercise" that results in "loyal, if necessarily imperfect, obedience to God's laws. ${ }^{" 38}$ While Una's clothing is covered, she mimics the Woman whose obedience is "imperfect." disappearances... of spiritual insight. ${ }^{, 40}$ She can make mistakes within Faery Lond because she is not yet redeemed. Once the Edenic kingdom is restored, though, she no longer needs to live in this dual state. By the twenty-first stanza of the final canto, she has thrown off her black cloak and shown herself as the whole and complete, unified Church.

Redcrosse does not possess this same duality. He is still a sinful man. For though he has done penance and received forgiveness, he is not yet a redeemed saint. There is still, apparently, work to be done, and while Una is removed permanently to this Other space outside of time and Faery Lond, Redcrosse remains in it but for a moment. He steps into the Edenic and timeless space where he would have married Una, only to be thrust back to Faery Lond and the vow he made to Gloriana. While he is at his marriage ceremony, he stands as a redeemed man. Not allowed to stay there, though, he is yanked back in a surprising twist:

Her ioyous presence and sweet company In full content he there did long enjoy, Ne wicked enuy, ne vile gealosy

\footnotetext{
${ }^{38}$ Gless, Interpretation and theology, 84 .

${ }^{40}$ Ibid., 20.
} 
His deare delights were hable to annoy:

Yet swimming in that sea of blisfull ioy,

He nought forgott, how he whilome had sworne,

In case he could that monstrous beast destroy,

Vnto his Faery Queene backe to retourne:

The which he shortly did, and Vna left to mourne. (FQ I.xii.41).

He almost escapes it; he makes it to the last two lines of the Book's penultimate stanza: then, remembering his vow, in a twelve syllable line, leaves and leaves Una to mourn. The shift is so sudden that the reader is left shocked. Not bothering to explain the absurd departure, the narrator draws us onto some sort of metaphorical ship which transitions us into the second Book. The End of time is not yet, and Redcrosse is not allowed to remain outside of it.

MARRIAGE AND THE APOCALYPSE 
Arthur and Una are the only two characters with the ability to exist both in and out of the temporal-spatial bounds of Faerie Lond. That they share this quality with each other and not with Redcrosse is especially important because it acts as a way of distinguishing them, of separating them from all the other characters in the narrative. There is something special about them; they are integral parts of the Biblical narrative, of the Apocalyptic drama that takes shape both in the text and in the early modern English space in which Spenser was writing.

This similarity of Arthur to Una becomes even more important as it relates to the prospective marriages that pervade the poem, for these marriages are continually delayed. For example, before Una and Redcrosse can have their relationship consummated, either publically or privately, the opportunity for a union is snatched away from the characters and the reader. A pattern of deferred marriages that persists throughout the entire poem begins here. None of the promised marriages of the major characters ever occur; Arthur/Gloriana, Redcrosse/Una, Artegall/Britomart, Scudamour/Amoret—none of these couples ever quite make it to the proverbial altar, despite numerous opportunities to do so. The reader is left wondering why the wedding ceremony in Book I is cut short, why Arthur's narrative in the house of Alma is not complete, why Merlin's prophesy for the union of Artegall and Britomart is never actualized.

Of course, the easy answer to these questions is that deferring marriages allows for the narrative to continue. Spenser's plan of writing twenty-four Books indeed would have needed all the traction it could get, and final resolution, the kind that marriage would bring in most of the above cases, would end these characters' places in the text. 
But I think that because this issue is so far-reaching, because it stretches through the entirety of the poem as we have it, this easy answer will not do.

I propose another theory, then. Una does not marry Redcrosse finally, because she cannot. A redeemed Church cannot be married to a sinner existing temporally; it can only be married to the resurrected Christ beyond time. What happens here is something that, surprisingly, no critic has previously addressed. The promised marriages of Una to Redcrosse and Gloriana to Arthur never happen because these pairings are mismatched. I have shown that the Arthur of Book I is representative of Christ, and Una of the Church. If the Church can only marry Christ, and if we follow the logic of Spenser's allegory, then Una should be marrying Arthur. If we follow the allegorical interpretation all the way through this Book, it would make sense that Una and Arthur would be paired in a sort of heavenly, Platonic ideal marriage relationship that provides the standard for all other marriages because this follows the pattern of the Christian allegory.

The Arthur/Gloriana pairing is similarly mis-matched: Christ is not betrothed to his Bride the Church, but to Gloriana, the "fairest Fary Queene," the "soueraigne Dame," the political ruler of Cleopolis (x 58.3, 59.7). We know from the Letter to Raleigh that Gloriana is (in part) a Faery Lond representation of the historical Queen Elizabeth, the ruler of Raleigh and Spenser's England. ${ }^{41}$ Spenser pairs a religious representation with a political representation in both couples instead of following the Biblical precedence of pairing Church with Christ. This would leave England (Elizabeth/Gloriana) to join with the English patron saint - George. For if we follow the allegory further, Redcrosse seems better suited to Gloriana than to Una. He effectively leaves Una for Gloriana: he "had

\footnotetext{
${ }^{41}$ Spenser, The Faerie Queene, 716.32-34.
} 
sworne / ... / Vnto his Faery Queene backe to retourne" (FQ I.xii 41.6-8; italics mine). Una is (justifiably) left to mourn at this second desertion for another woman. Redcrosse and Una never meet again in the course of this narrative; the last appearance the knight makes finds him still separated from Una (III.ii).

Many critics skate around this problem by assuming that Redcrosse becomes a Christ figure after his defeat of the dragon. If he is the Christ figure, then his betrothal to the Church is certainly à propos. Escobedo cites Frank Kermode and Carol Kaske as critics who see Redcrosse as " 'Christ himself." "42 I add to these critics John King, who claims: "Redcrosse is a variation of a warrior named Faithful and True, that is, Christ, who rides upon a white horse and defeats the forces of Antichrist.... The knight's betrothal to Una re-creates the relationship of Christ the Bridegroom and the Spouse as a type for the 'true' church." ${ }^{43}$ These critics, however, shunt the other Christ figure, Arthur, out of the way and fail to explain where he has gone.

Michael Leslie argues against such critiques by remarking that "the Red Cross Knight is never equated with Christ, even on the final day. ${ }^{, 44}$ Additionally, he affirms that though man can become perfect, such a transformation can only occur with the End of Time: "Perfection for man is to become in Christ [rather than Christ himself] as the Red Cross Knight does on the third day of his final battle. ${ }^{, 5}$ Once this final battle occurs, it ushers in what is supposed to be Apocalypse and the End, and it is only here that true

\footnotetext{
42 Qtd in Escobedo, 122.

${ }^{43}$ King, Spenser's Poetry, 74-75.

${ }^{44}$ Leslie, "Fierce Warres,"114; italics mine.

${ }^{45}$ Ibid., 115.
} 
holiness and perfection can be achieved. My interpretation fits well with Leslie's, for reasons I will lay out.

Escobedo does point out that "the line between Christ and his types was [for Elizabethans] blurrier than we usually grant," ${ }^{46}$ and this needs consideration. After mapping out the entire Passion story within Book I that sets Arthur up as the singular, past, present, and future Christ, though, it is difficult to imagine another Christ-figure within this part of the narrative. So difficult, in fact, that King ignores him and makes Redcrosse the key figure instead. More troubling than this, though, is that this reading does not explain why Redcrosse deserts Una. If Christ and the Church were really to unite, it would be the ultimate marriage that none could put asunder. But because Redcrosse is not a Christ, only a redeemed saint and forgiven sinner, he leaves his bride on their wedding day.

It is, of course, not enough to assert that simply because one Passion story exists in this Book, there shouldn't be another Christ, and indeed, at first reading Redcrosse does seem to function as a type of Christ in his defeat of the dragon. There are other reasons, though, that definitively seal Redcrosse not as a Christ, but rather as a saint. He defeats the dragon, which, according to Bauckham, is symbolic of the devil, of the "primeval force[..] of evil, ${ }^{47}$ and which resembles the apocalyptic dragon of Revelation. ${ }^{48}$ The one who defeats the apocalyptic dragon is the one who defeats evil, as Christ does in his crucifixion and resurrection. Bauckham says that this dragon is "destined for ultimate

\footnotetext{
${ }^{46}$ Escobedo, Nationalism and Historical Loss, 122.

${ }^{47}$ Richard Bauckham, The theology, 90.

${ }^{48}$ Wofford, The Enfolding Dragon, 163.
} 
defeat by the divine Warrior at the last day. ${ }^{, 49}$ Christ is this divine Warrior, and so to have Redcrosse slay the serpent creates a strong tie between Christ and the knight. It is completely understandable that critics would read Redcrosse as one who becomes a Christ figure in the last two cantos of Book I when Arthur has exited the narrative. But this conclusion can be reached only by disregarding alternate interpretations of Redcrosse, as well as Arthur's situating in time and his dragon-crested helmet.

As I proposed earlier, the spread and development of characters makes more sense if Redcrosse is read as a forgiven sinner who has become a saint than as a Christfigure. Other Scriptural allusions support this interpretation, especially when he is read as a saint resembling the apostle John. For both men are taken up onto a high mountain to see the New City, to glimpse the New Jerusalem, and both men see and praise its beauty. Redcrosse, taken up to Mount Contemplation, declares that where he once thought Cleopolis the "fairest Citty," he knows now that the heavenly New Hierusalem "does far surpas” the earthly city (I.x 57.4, 8). John writes of his experience: “And he [an angel] caryed me away in the spirit to a great $\&$ hie mountaine, \& he shewed me the great citie, holie Ierusale[m], descending out of heauen from God, Having the glorie of God: and her shining was like vnto a stone most precious, as a Iasper stone cleare as cristal" (Revelation 21.10-11). Redcrosse's language mimics John's in his description.

The allusive nature of the passage has been recognized for years. Most of Spenser's readers would have recognized the allusion to Revelation, and so I am not pointing out anything new in simply drawing comparisons. The conclusions that can be drawn by positioning Redcrosse as a type of John-like apostle, though, allow us to read

${ }^{49}$ Bauckham, The theology, 90. 
around the knight as another Christ. He has his own place, and need not be subsumed or swallowed into another type of Arthur. If Redcrosse does function like an apostle, it makes sense that he, like Christ, also possesses the power to kill the dragon. ${ }^{50}$

The scene on Mount Contemplation departs significantly from the Revelation text and apocalyptic feel, however, when Redcrosse starts to praise Cleopolis under the guise of praising the new Hierusalem. The praise seems misplaced, disrupting the mystical and spiritual theme that stretches through the whole of the canto. Leading up to the passage in question, Redcrosse hears of Christ and Heaven and the new Hierusalem (x.54-57), which parallels the passage in Revelation and the experience of John the Apostle. Contemplation teaches him these heavenly themes, themes which are so "high" that no tongue can describe them $(55.7,5-6)$. Then, in a very awkward moment indeed, Redcrosse suddenly gives the new city an underhanded compliment, underhanded because he uses it to praise Cleopolis and Gloriana as well. He tells Contemplation: Till now... I weened well, That great Cleopolis, where I haue beene, In which that fairest Fary Queene doth dwell, The fairest Citty was, that might be seene...

But now by proofe all otherwise I weene;

For this great Citty that does far surpas... (x.58 1-4, 7-8).

Of course, he does say that this new, "great" city surpasses the greatness of Cleopolis, but he still makes sure to use the opportunity to praise Gloriana. And then

\footnotetext{
${ }^{50}$ Before his ascension, Christ also granted protection to his apostles over snakes. See Mark 16.18, as well as Acts 28.3-6, for Pauline story about apostolic power over snakes.
} 
Contemplation chimes in to correct him. Venerable, wise Contemplation starts in on an homage to Cleopolis as the "fairest peece" (59.3), and elevates the earthly city to a sort of heavenly place, and Gloriana to a sort of deity. It is, Contemplation says, the place where knights may be "eternized," and may do their service to the "heuenly borne" Gloriana $(59.6,9)$. Dissenters will argue that the praise for the new Hierusalem is indeed greater than for the praise of Cleopolis, and it is true that both Redcrosse and Contemplation do assert the superiority of the new city. However, the praise for this city is undeniably used as an opportunity to also praise Cleopolis, and indeed to raise the earthly city to a heavenly status, complete with its own deity-like figure. It is also undeniable that Contemplation points Redcrosse towards Cleopolis, as if he understands that it is Gloriana that Redcrosse should really be looking for.

This is not merely an act of Spenser the courtier to curry favor with his Queen by praising her and her city. It is the revelation of Redcrosse's underlying desire to pursue not Una, but Gloriana. It is also the revelation of Contemplation as perhaps the wisest character of all in Book I, for he understands that Redcrosse must seek Gloriana and not Una, because he will eventually be recognized as "Saint George of mery England" (61.9). He must go to Cleopolis, to Gloriana, to reach sainthood. And when the knight does question Contemplation's urging to seek after the glory of this sainthood, asking whether he is to shun the love of Una, a love "so dearely bought" (62.6). This is the reply he receives: "What need of arms, where peace doth ay remaine, / ... and bitter battalies all are fought? / As for loose loues they' are vaine, and vanish into nought” (62.7-8). Contemplation answers him with a reproof and the accusation that the love-either for or of, the syntax is not clear-Una is only that of a "loose loue[...]" (9). 
Both the narrator and the text make clear that Una is not a "loose loue," however, so we are left to wonder about the discrepancy between the narrative and the words of Contemplation. We must look at Contemplation himself in order to address this problem. Contemplation, a seeming spokesman for Cleopolis, pins this description on Una without cause because he is trying to convince Redcrosse to leave her for Gloriana. He uses whatever argument he can to dissuade the knight from a union with the Church. It is clear that some of this rhetoric lingers in the mind of Redcrosse, for it makes an appearance later and succeeds in turning a wedding celebration into a mere betrothal ceremony.

Contemplation also gives Redcrosse his new name, Saint George. Significantly, it is Contemplation who names him, for in his praise of Cleopolis he betrays his alignment with the values and objectives of that city. He names the knight the defender, the protector, of England; this England is Elizabeth and is also Gloriana. The behest of a new title draws the knight away from a heavenly existence, and plants him firmly within the realm of England and Elizabeth/Gloriana. Redcrosse as Saint George will be the one who will draw the nation together, who will be the "frend... of mery England" (61.7-9). It is interesting that Redcrosse is the one who takes on this role. One would think that Arthur would be the one to do this; he is supposed to play the role of protector, and essentially, husband, of England/Gloriana. In such a light, Escobedo writes of Spenser's use of Arthur: "[he] use[s] narrative representations of nationhood [through the character of Arthur] to mediate what [he] perceives as a troubling breach in history and in the process attempt[s] to bring together the English past, present, and near future in a complete and 
continuous story." ${ }^{51}$ Although Escobedo is writing particularly about bringing the history of England together, Arthur still functions in his interpretation as one who draws England together and stands in as its emblem. ${ }^{52}$ Not so here, though. Here, it is Redcrosse who, in being given the burden of succoring England, supplants Arthur's role. It is here as well that he is allied unmistakably with Gloriana and pointed away from Una. Contemplation on the Mountain foresees the potential problems that the current marriage arrangements present and tries (successfully) to steer Redcrosse away from his intended.

Reading Una as Elizabeth, as both King and Escobedo do, is equally problematic in circumventing the gap I have identified. If Gloriana (at least partially) represents Elizabeth, and Elizabeth and Una are the same, then in searching for Gloriana, Arthur is actually just searching for Una the Church. Positioning Elizabeth as the true Church, Escobedo writes that "it is possible... that Elizabeth has been betrothed to Christ.",53 While such a reading may be helpful in understanding the historical context, it firstly reduces these characters to simple types of one another, and it secondly places too much emphasis on Elizabeth as the Bride of Christ. Richard Bauckham, in his influential Tudor Apocalypse, cautions against "exaggerat[ing]" the apocalyptic imagery applied to Elizabeth by her subjects. ${ }^{54}$ He notes that such images were applied sparsely and with

\footnotetext{
${ }^{51}$ Escobedo, Nationalism and Historical Loss, 3.

${ }^{52}$ Spenser does have Arthur playing the role of the gatherer of historical ends in Book II, but the Prince never quite fulfills this role either, because the historical text that the Prince reads from breaks off just before it reaches his prophesy.

${ }^{53}$ Escobedo, Nationalism and Historical Loss, 122.
} 
"restraint,", 55 and that the apocalyptic tradition which most Elizabethans adhered to "was usually sufficient to keep Elizabeth in her place."56 According to Bauckham, then, Elizabeth was not the true Church, only a defender of it. She is not Una.

Scholars have never fully analyzed what kind of impact a union between Una and Arthur could have on the text. Richard A. Levin does gesture towards the possibility of a relationship between the two, saying that the language in the text "need not suggest flirtation, but it can." ${ }^{, 57}$ His essay acknowledges the possibility for a relationship, but argues that while Una "glances at the thought that she and Arthur are a match that might have been," 58 they each remain loyal to their respective partners ${ }^{59}$ and that at least for Una and Redcrosse, the story ends happily. ${ }^{60}$ He explains the sudden departure of Redcrosse as "only a type of Christ's marriage to the True Church at the end of time.",61 While I agree with this premise and will later address the Apocalyptic, end of time explanation, Levin does not address the failure of the allegorical structure in the mispairing of Una and Redcrosse. The passing "flirtation" between Una and Arthur is not

\footnotetext{
${ }^{54}$ Richard Bauckham, Tudor Apocalypse: Sixteenth century apocalypticism, millennarianism, and the English Reformation: from John Bale to John Foxe and Thomas Brightman (Oxford: The Sutton Courtenay Press), 1978, 128.

${ }^{55}$ Ibid., 128.

${ }^{56}$ Ibid., 129.

${ }^{57}$ Richard A. Levin, "The Legende of the Redcrosse Knight and Una, or of the Love of a Good Woman," SEL: Studies in English Literature, 1500-1900, 31.1 (1991): 13.

${ }^{58}$ Ibid., 16.

${ }^{59}$ Ibid., 15.

${ }^{60}$ Ibid., 22.

${ }^{61}$ Ibid., 20.
} 
just a passing flirtation. Their interaction is a crucial moment of potential for a marriage that could take place, instead of being perpetually delayed.

Michael Leslie argues that the moment the two come together, there is a marked change in the mood of the text. ${ }^{62}$ In the seventh canto, Una is perhaps at her lowest point; she has just received the arms of Redcrosse that seem to indicate his death. Arthur enters the text, though, and suddenly Una finds her hope. Leslie writes: “The depression fostered by the return of the 'ruefull moniments' of the Red Cross Knight is eliminated by the magnificence of Prince Arthur's arms; as Kathleen Williams implies, the poem seems suddenly spacious and optimistic once more." ${ }^{63}$ In this reading, the helmet of Arthur, as well as the rest of his armour, here plays a role in first interaction of Arthur and Una. Because Arthur's arms "in general speak his triumph," ${ }^{, 64}$ the memory of Redcrosse is momentarily pushed aside. I extend this reading as further evidence for a possible courtship of Arthur and Una: of course the poem seems spacious and optimistic once more. The Bride is meeting her Husband. The two are at last coming together.

This coming together of the two seems purposeful. It is by "good hap" that they meet ( $F Q$ I.vii 29.1), that Una chooses to bare her soul to a stranger, and that this stranger is a force powerful enough to save Redcrosse. Their conversation is one of equals, and their exchange of maxims reveals a well-spoken and quick-witted Una who can match Arthur's verbal stylings:

\footnotetext{
${ }^{62}$ Leslie, Spenser 's 'Fierce Warres and Faithfull Loves', 56.

${ }^{63}$ Ibid., 56.

${ }^{64}$ Ibid., 56.
} 
O but (quoth she) great griefe will not be tould,

And can more easily be thought, then said.

Right so (quoth he) be he, that neuer would,

Could neuer: will to might giues greatest aid.

But griefe (quoth she) does greater grow displaid,

If then it find not helpe, and breeds despaire.

Despaire breeds not (quoth he) where faith is staid.

No faith so fast (quoth she) but flesh does paire.

Flesh may empaire (quoth he) but reason can repaire. (vii 41).

The way the syntax is set up, the "quoth she"/ "quoth he," becomes visual and aural evidence of the back and forth exchange. Although Arthur eventually convinces her to reveal the cause of her grief, Una shows that she can answer his arguments quickly, frequently, and succinctly.

This verbal matchup is significant particularly because it contrasts so with Una's and Redcrosse's conversation. The reader is not ever privy to much conversation between the two, and seems to remember instead the incident in which Una admonishes Redcrosse to "Fly fly" from Errour (I.i 13.8), an admonishment which he foolishly ignores. Then there is the whole miscommunication that occurs through Archimago and results in a brokenhearted Redcrosse and a lost and forsaken Una. The communication that occurs here between Arthur and Una, however, stands out as markedly different. It is equally yoked, so to speak, and both parties understand each other well. 
Nowhere is this verbal power more evident than in Arthur's naming, which Una performs in the ninth canto. Hamilton writes of Una as Truth ${ }^{65}$ and as such attributes agency to her in this naming. Hitherto that point, Arthur is known only as "the Prince," or "impe," or "the knight," but never "Arthur." She has some sort of power over him such that while he cannot, or will not, speak his own name for himself (xi 2.7), she knows it and can declare it for him. Just as the representative of Cleopolis (Contemplation) names Redcrosse and creates a bond between the knight and the Earthly city, Una's naming of Arthur creates a similar bond between the Prince and the heavenly city, and the heavenly city's bride.

They converse easily with each other, and even when Redcrosse has been rescued, he is noticeably absent from their dialogue about Arthur's lovelorn past. ${ }^{66}$ Arthur asserts that he is "blest" to have helped Una ( $F Q$ I.ix 7.7), and she calls his the "gentlest hart on ground" (9). The emphasis on the "ground" is used again by Una later in the text, and is picked up by Arthur as similar language in which to speak about the unpredictability of love. Arthur is describing his vulnerable state as a young man when love finds him unawares; he says, "Nothing is sure, that growes on earthly grownd" (ix 11.5). Several stanzas later, Una echoes this: "True Loues are often sown, but seldom grow on ground" (16.9). The sense of an unreliable or unpredictable world is revealed in both cases: we can be sure of nothing, and especially not love. That both Arthur and Una express this sentiment indicates that they are acutely aware that love can go awry.

\footnotetext{
${ }^{65}$ Hamilton, note to I.ix 6.5.

${ }^{66}$ Levin, "The Legend of the Redcrosse Knight and Una," 14.
} 
This line by Una is preceded by several that would seem to be in praise of the love between Arthur and Gloriana:

O happy Queene of Faries, that hast fownd

Mongst many, one that with his prowess may

Defend thine honour, and thy foes confownd:

True Loues are often sown, but seldom grow on grownd. (16.6-9).

Una seems to acknowledge that the love between Arthur and Gloriana is one that is unique and prosperous. The last line in particular seems to elevate this relationship as one that achieves something special. Read in context of the previous few stanzas, however, and as a response to Arthur's narrative, this last line becomes more of a criticism than a statement of praise. Arthur is not telling a happy love story; he is "pale" (16.1), and describes his nine-month search for Gloriana as "vain" (15.9). Una has nothing to praise. Or, if we insist on reading this line as praise, it is strangely out of place with and inappropriate to the struggle that Arthur speaks bitterly about. The relationship that Arthur has with Gloriana is an example of one of the many relationships that does not grow on the ground: it may have been sown on the ground, but it is certainly not growing, for one of the two people is nowhere to be found. It seems far-fetched to imagine Una praising the relationship that Arthur has just recounted; it seems more likely Una's comment on the futility of a love that is ever-desiring but never fulfilled.

That both Una and Arthur locate their comments about futility and uncertainty in the spatial area of "grownd" is significant because it shows their mutual understanding. Margreta de Grazia in Hamlet without Hamlet discusses the connotations of "grownd" and "earth" in early modern England, noting that the ground is cursed as a result of the 
Fall of man, and that reminders of this curse permeated that society. She writes: "Every burial service in compliance with Elizabeth's Book of Common Prayer served as a reminder of this elemental affinity: 'Earth to earth, ashes to ashes, dust to dust'.... As God raised man from the dust, so death reduced him back to it. ${ }^{367}$ When Una and Arthur then name the ground the place where earthly love is localized, they allude to this connection between death and the ground. It is possible that earthly love, the love they are tied to in Gloriana and Redcrosse, is death to Arthur and Una, because it means another deferral of the End that would come with the union of the Church and the Bridegroom.

On the "grownd" is Arthur bound to look for Gloriana, and like the love that seldom grows on this ground, his search does not yield any fruit. It is really very puzzling that Arthur's search for Gloriana is perpetually unfruitful and that he never once makes contact with her throughout the course of six Books. This inability to connect poses obvious problems for Arthur and Gloriana's intended marriage, for where there is no contact there can be no consummation and no marriage. Una apparently has no problem locating the Queene, for she reports that she "sped" straight to court (I.vii 46.5). Redcrosse also knows where the court and Gloriana are, for he dwelt there before agreeing to leave the city to defend Una (47.2). In view of this, it seems that three possibilities emerge: either Arthur is a bungling and inept knight; or, Gloriana does not want to be found by Arthur and possesses the power to hide herself; or, that deep in some part of Arthur, it is he who does not really want to find her. But we know that Arthur is not inept, at least not in this Book, as I hope I have convincingly argued. We also know

${ }^{67}$ Margreta de Grazia, Hamlet without Hamlet (Cambridge: Cambridge UP, 2007), 32. 
that Gloriana, in coming to Arthur either in a vision or in person, bade him love her (I.xi 14.2). The only other alternative, then, is to assume that Arthur does not really want to find Gloriana, that he is tortured by the very process of searching for her.

It seems that Redcrosse too is uncomfortable with the idea of ending up with his intended Una. In a few telling lines, he reveals this uncertainty; after hearing Una's response to the Gloriana story, he declares his love for the Queene, a love that will (perhaps) surpass his love for Una: “Thine, O then, said the gentle Redcrosse knight, / Next to that Ladies loue, shalbe the place, / O fairest virgin, full of heauenly light" (ix 17.1-3). Hamilton notes the uncertainty implicit in the language of this passage, writing that while the lines could be read as Redcrosse's declaration of his love for Una before that of Gloriana, the knight "more likely" means that his love for Una will go "next after his love for the Faerie Queene. ${ }^{\prime 68}$ Levin interprets the lines as Redcrosse's vow that his love for Una will match Arthur's for Gloriana. ${ }^{69}$

Whichever way readers choose to read the passage, we are forced to acknowledge its haziness. There is no concrete declaration of love for Una above all others. Ultimately there is only ambiguity for Redcrosse, and an ambiguity which culminates in a bride left forlorn at the altar on her wedding day. This ambiguity, coupled with Contemplation's urging towards Gloriana in canto $\mathrm{x}$, acts as forerunner to Redcrosse's sudden exit at the end of Book I. It is as if we should have been expecting an exit the whole time.

Something is not right between the pairings as they have been presented within the text, and that something is that the pairings were wrong to begin with. Redcrosse and Una

\footnotetext{
${ }^{68}$ Hamilton, 17.1-3n, italics mine.

${ }^{69}$ Levin, "The Legend of the Redcrosse Knight and Una," 16.
} 
were not meant to marry, in the same way that Arthur and Gloriana were not meant to marry. The inability of these couples to find their "true" partners leads to greater consequences, at least as it relates to Arthur's character.

Of course, many interpretations of Una and Arthur are possible, and neither of them need be read in this strictly allegorical and Biblical way. Reading them as Christ and the Church, however, allows for a wider understanding of Arthur's character. After his exit from Book I, he ceases to function as the Christ figure. This first Book associates him so closely with Christ that it narrates the entire Passion story through him. By the time of his reappearance in Book II, his character as the flawless Christ has begun to unravel.

The missed marriage opportunity for Arthur and Una is representative of the missed marriage opportunity of Christ to the Church. When Arthur leaves to pursue Gloriana, the figure that Elizabeth Bellamy calls "a narrative elegance,"70 the chance for apocalypse is missed, for the marriage supper of the Lamb signals apocalypse. Just as Redcrosse is snatched away from the timeless space, the End is once again delayed when Christ and the Church meet in Faerie Lond only to be parted. As Levin mentions, Redcrosse's departure can be explained in terms of apocalypse. Just when it seems that the end of time has come and that the marriage supper is to occur, it does not, because Redcrosse is not Christ, only Arthur is. And so the opportunity for the end of time and the beginning of a timeless Heaven disappears when Arthur and Una fail to recognize each other for what they are.

\footnotetext{
70 Elizabeth Bellamy, "Reading Desire Backwards: Belatedness and Spenser's Arthur," South Atlantic Quarterly, 88.4 (1989): 802.
} 
From this point on, the chance for the End is thwarted, as are the marriages that represent this end. True to her redeemed existence in a heavenly place, Una disappears from the text, never to be seen or heard from again, and Arthur loses his position as Christ to become a humanized, flawed, and at times almost bungling, knight. This devolution, as it were, of Arthur's character leads me to disagree with Christopher Bond's reading of the Prince as "one who begins preeminent in power and virtue but grows into yet greater perfection over the course of the poem.. ${ }^{, 71}$ It seems that once marriage to Una ceases to be an option, once Apocalypse is thwarted, Arthur's magnificence diminishes and his tenure as the perfect Savior is ended.

This gives The Faerie Queene a poignancy often missed, I think, by critics. It humanizes the characters that look to and hope for an End to the evils and the sorrows of Earthly living, but are perpetually denied it. This thwarted End, this failed hope, is not only present in the mis-pairing of Arthur and Una, but is part of every deferred marriage in the rest of the poem. Whether or not we would have seen the fulfillment of these hopes by the twenty-fourth Book, we will never know. As it stands from what we do have, these characters linger forever in a space of anticipation and denial of the End. This becomes clearer as the poem progresses and the characters move from moment to moment in a Faery Lond stripped of its potential to foresee and await and expect apocalypse. Contrary to the reading of many critics, the end of Book I is a sad one. It is not a Book that stands on its own, that is neatly folded and put away in opposition to the other Books in the poem (especially Books 3 and 4). It is as loose-ended as these other Books, because the

\footnotetext{
${ }^{71}$ Christopher Bond, Spenser, Milton, and the Redemption of the Epic Hero (Lanham, Maryland: Rowman \& Littlefield Publishing, 2011), 143-144.
} 
denial of apocalypse is present from the moment Arthur leaves Una, and this denial seeps into and permeates the rest of the poem. It is a disappointed Book, a series of characters whose pain is not assuaged, and whose hopes are ever to be delayed in the deferral of the End.

We see an attempt on the part of Spenser to wrap up his first Book and to give it a sense of closure with the inclusion of a heavenly wedding. Thomas Cain also finds apocalyptic significance in the number of stanzas in the final canto (forty-two), noting this as matching the forty-two months of Antichrist's tyranny. ${ }^{72}$ It is as though Spenser tries to hold his story together to the End, both of the text and of time, but fails. For in Redcrosse's departure we are dragged back into the realities of the world, a world in which the knight himself will never achieve his quest to serve Gloriana, and in which Arthur himself will cease to look for her when the possibility of a new woman presents itself.

\footnotetext{
${ }^{72}$ Thomas H. Cain, Praise in The Faerie Queene (Lincoln: U of Nebraska P, 1978), 81-82.
} 


\section{CONCLUSION}

As the poem moves past its first Book, its positioning as a markedly Christian poem shifts into a classical one. The virtue of holiness is exchanged in Book II for the Aristotelian virtue of temperance. This change situates the poem firmly within the realm of an earthly, sinful place. Watkins points out that this virtue requires a sinful space to reside in because it must contain the possibility for intemperance and extreme behavior. ${ }^{73}$ In contrast to perfect holiness, temperance can be achieved in some measure in Faery Lond, for Guyon as hero passes through the temptation of Mammon's cave and the Bower of Bliss and comes out, if not unscathed, at least alive. Holiness, though, can never be completely achieved within the bounds of Faery Lond; the characters in this poem, as exemplified by Redcrosse, are still sinner-saints who will only become holy when they reach heaven. Holiness is a heavenly virtue and belongs in a heavenly space.

After Book I, however, the poem no longer leaves room for a heavenly space. Although Anthea Hume argues succinctly against this and against A.S.P. Woodhouse's theory that Book I is situated on a "religious level" "74 in the order of grace, while Book II resides in a type of natural order, it is difficult to deny the bevy of classical influences that make their way into the text after Book I. Of course, there are classical allusions in Book I as well as Christian ones, as Wofford points out in her reading of Arthur's armor

\footnotetext{
${ }^{73}$ John Watkins, "Spenser's Poetry and the Apocalypse," in Early Modern English Poetry: A Critical Companion, ed. Patrick Cheney, Andrew Hadfield, and Garrett A. Sullivan Jr. (New York: Oxford UP, 2007), 94.

${ }^{74}$ Quoted in Anthea Hume, Edmund Spenser: Protestant Poet (Cambridge: Cambridge UP, 1984), 59.
} 
as influenced by The Aeneid and The Iliad. ${ }^{75}$ Overall, though, the elevated religious themes which permeate Book I seem to diminish as the poem moves on.

One of the reasons for this, I believe, is that Arthur has ceased to function as a Christ-figure. As I have shown, the Arthur of Book I is the Christ of Faery Lond. Once he as the Bridegroom misses his opportunity to marry the Bride Una, he no longer meets the standard of perfection that his positioning as Christ requires. This is his first in a series of many failures. He seeks out the wrong woman, and as a result of such a failure, cannot be Christ.

His failures increase as the narrative progresses. In contrast to his stunning performance in the battle against Orgoglio, Arthur is nearly killed by Maleger in Book II. He cannot figure out how to beat this strange foe, and the effort it takes to do so drives him to "his wits end" (II.xi 44.1). He is forced to leave the battlefield wounded and close to death:

Thus now alone he conquerour remains;

Tho cumming to his Squyre, that kept his steed,

Thought to haue mounted, but his feeble vaines

Him failed thereto, and serued not his need,

Through loss of blood, which from his wounds did bleed,

That he began to faint, and life decay:

But his good Squyre him helping vp with speed,

With steadfast hand vpon his horse did stay,

And led him to the Castle by the beaten way. (II.xi 48)

\footnotetext{
${ }^{75}$ Wofford, "The Enfolding Dragon," 140-150.
} 
Although he is initially announced as a conqueror, Arthur does not seem to be much of one, with the life running out of his veins. Arthur perhaps has won the battle, but his inability to understand the type of battle he must fight with Maleger represents the loss of something other than his blood. I believe it suggests a period of total incompetence on his part to do what must be done. This is certainly a much different Arthur than the one to which we are privy in Book I.

The failure in this fight alone is enough to indicate the loss of Arthur's power and magnificence. But the unraveling of the perfect Arthur becomes ever more insidious as Book III progresses and the Prince begins to literally chase the fleeing Florimell. It is at this point that he abandons all pretense of searching for Gloriana and allows his desire for this other woman to carry him across and through Faery Lond. Arthur's pursuit of Florimell in Book III has bothered some critics, but perhaps it has not bothered them enough. While Sheila T. Cavanaugh points to it as the possibility of "untoward concupiscence" on the part of Arthur, ${ }^{76}$ C.S. Lewis merely interprets Florimell as the Platonic rendering of Gloriana, the Ideal that Arthur is seeking out. ${ }^{77}$ While these readings are interesting, I believe they become even more meaningful when seen in the context of my theory about the relationship between Arthur and Gloriana. Arthur, not really wanting to find his intended, and having ceased to signify Christ, allows himself to be sidetracked by Florimell, as if his quest for Gloriana no longer plays any significant role in his purpose in Faery Lond.

\footnotetext{
${ }^{76}$ Sheila T. Cavanagh, “'Beauties Chace': Arthur and Women in The Faerie Queene," in The Passing of Arthur: New Essays in Arthurian Tradition, ed. Christopher Baswell and William Sharpe (New York: Garland Publishing, 1988), 217.

${ }^{77}$ C.S. Lewis, The Allegory of Love: A Study in Medieval Tradition (London: Oxford UP, 1936), 314.
} 
Although Arthur is physically sidetracked by Florimell, he continues to hint at his feelings for Una even in Book III. He cannot, though time has passed and he has fought other battles and met other women, forget her. Lewis notes that in Arthur's lament to the night, the Prince actually mentions Una, albeit under the name "Truth" ${ }^{78}$ Lewis quotes the following passage as evidence:

The children of day be the blessed seed, Which darkness shall subdue, and heauen win:

Truth is his daughter; he her first did breed, Most sacred virgin, without spot of sinne.

Our life is day, but death with darkness doth begin. (III.iv 58.5-9).

Some might respond that the lament is really about Florimell, but the few lines before the beginning of the lament are telling: "Oft did he wish, that Lady faire mote bee / His faery Queene, for whom he did complaine: Or that his Faery Queene were such, as shee" (III.iv 54.6-8). Arthur seemingly has no problem in replacing one woman for the other, as is exemplified here, and so a song that is about Gloriana is also a song about Florimell, which is also a song about Una. In fact, it is not really a song about Florimell and/or Gloriana at all, for neither appears in the poem. It is Day and Night that figure prominently, but the only mention of a woman is (predictably) that of Una.

Lewis agrees with Hamilton that Una is Truth, ${ }^{79}$ and claims that as the daughter of the emperor of the East, and therefore of Light, it "is no accident that Truth, or Una,

\footnotetext{
${ }^{78}$ Ibid., 314.

${ }^{79}$ See page 32 herein.
} 
should be mentioned here. ${ }^{\prime 80}$ And indeed, Una is Truth, and Arthur here does call her the "blessed seed" (5). The "blessed" takes us back to his final encounter with Una, whom he acknowledges he was "yet blest" to have met (I.ix 7.7). Una is the "blessed seed" (italics mine), the seed "that grow[s] on ground" that does not die, for she is Light and Life. Arthur admits in canto 9 that what "grow[es] on earthly ground" (ix 11.5, italics mine) is not fruitful and leads to death, but here he contrasts the death of earthly seed with the blessed seed of Una. A union with her offers the promise of some fulfillment, some hope for a future that can be fruitful. Even in his praise for her, though, this hope is empty and unfulfilled; this last attempt to recall and evoke Una's presence is "vain," just like Arthur's search for Gloriana, because it comes in the middle of a lament to the Night that Una cannot hear.

The last we see of Arthur in the entirety of the poem as we have it, he leaves Book VI to go "onward still / On his first quest, in which did him betide / A great aduenture, which did him from them deuide" (VI.viii 30.7-9). This "first quest" is ostensibly the quest to find Gloriana. After almost an entire six Books, Arthur is still looking for what he will never find. Although he is "back on track," so to speak, in searching for one woman and not chasing every skirt he sees, he still does not get it right. He will never find Gloriana because she is not available to him, and was never meant to be. It was Una he should have been looking for, it was always Una. But he can never return to Una, for after Book I he has ceased to be a Christ-figure in the orthodox sense. He is, and always will be, alone.

${ }^{80}$ Ibid., 314. 
It is not only Arthur who is left in a sort of Purgatorial state of unfinishedness. Hamilton rightly notes that while this quest divides him from the other characters in the text, it also divides him from us as readers. ${ }^{81}$ I would like to extend this to include all the characters in the poem that do not have a fixed end. Because of the unfinished nature of the poem, characters like Una are perpetually waiting for an end. But an end will never come, for the poem itself cannot tell us. These characters are left dangling in this middle space of literature, forever mourning their inability to come to some sort of resolution. They cannot move towards finality and so are trapped in a space and time that will never see the End.

Most of all, though, these characters are fixed within Time itself, for the time that continues is the time that forestalls the End. It is this time that Spenser cannot abolish, that continues despite efforts by his contemporaries to wield apocalyptic rhetoric. It is this circular time that leads the characters of The Faerie Queene ever in a circular pattern of hope for fulfillment and, ultimately, unfulfilled desire. Arthur, though, is lead back to the hope for fulfillment, which we see exemplified by his yearning for Una in the lament to the Night, just like he is lead back to "his first quest." As long as his desire is for Una, though, it will not reach its end within the scope of the poem, for apocalypse is yet to come and renew and remake that Faery Lond. Arthur and Una must remain in their dual states of being until Time ends and releases them from their temporal and spatial restrictions.

Perhaps it is for this reason that Milton did not finally choose Arthurian romance for his own epic poem. In choosing to tell the story of paradise lost and its ultimate

\footnotetext{
${ }^{81}$ Hamilton, The Faerie Queene, VI.viii 30.9 note.
} 
redemption through Christ, he is able to look forward to a final day of renewal. Whereas Spenser is forced to leave the possibility of this fulfillment within the boundaries of Faerie Lond, Milton can project that fulfillment into the redeeming work of Christ in a real world setting. He is not ultimately restricted to a fantasy world where the Christfigure is only a figure, a representation, and not the person himself. Because Arthur fails, because he cannot sustain his positioning as Christ, final redemption is not possible for Spenser's world and its characters in the way that it is for Milton's. It takes the entirely different genre of epic in Milton's hand to fashion a Christ that does not ultimately suffer a diminished magnificence, but can fully imitate the Biblical Christ of orthodox Christianity. In this way, he can do what Spenser and Spenser's Arthur cannot-he can offer a Christ that will one day, finally, bring an End to time and space. 


\section{REFERENCES}

Bauckham, Richard. The theology of the Book of Revelation. Cambridge: Cambridge UP, 1993.

Tudor Apocalypse: Sixteenth century apocalypticism, millennarianism, and the English Reformation: from John Bale to John Foxe and Thomas Brightman. Oxford: The Sutton Courtenay Press, 1978.

Bellamy, Elizabeth. "Reading Desire Backwards: Belatedness and Spenser's Arthur." The South Atlantic Quarterly, 88.4 (1989):789-809.

Bond, Christopher. "The 'Legend of Holinesse' and the Fall of Man: Spenser's Faerie Queene 1 as Milton's Original for Paradise Lost 9 and 10." In Uncircumscribed Mind: Reading Milton Deeply, edited and introduced by Charles W. Durham and Kristen A. Pruitt, 206-221. Selinsgrove, PA: Susquehanna UP, 2008.

- Spenser, Milton, and the Redemption of the Epic Hero. Lanham, Maryland: Rowman \& Littlefield Publishing, 2011.

Cain, Thomas H. Praise in The Faerie Queene. Lincoln: U of Nebraska P, 1978.

Cavanagh, Sheila T. “ 'Beauties Chace': Arthur and Women in The Faerie Queene.” In The Passing of Arthur: New Essays in Arthurian Tradition, edited by Christopher Baswell and William Sharpe. 207-218. New York: Garland Publishing, 1988.

De Grazia, Margreta. Hamlet without Hamlet. Cambridge: Cambridge UP, 2007.

Escobedo, Andrew. Nationalism and Historical Loss in Renaissance England: Foxe, Dee, Spenser, Milton. Ithaca, NY: Cornell UP, 2004.

Geneva Bible, The: a Facsimile of the 1560 edition. Introduction by Lloyd E Berry. Peabody, Massachusetts: Hendrickson Publishers, 2007.

Gless, Darryl J. Interpretation and theology in Spenser. Cambridge: Cambridge UP, 1994.

Hamilton, A.C., ed. The Faerie Queene. $2^{\text {nd }}$ ed. Harlow, England: Pearson Education, 2007.

Hume, Anthea. Edmund Spenser: Protestant Poet. Cambridge: Cambridge UP, 1984.

Kaske, Carol V., ed. The Faerie Queene book one. Introduction by Carol V. Kaske. Indianapolis: Hackett Publishing, 2006. 
King, John N. Spenser's Poetry and the Reformation Tradition. Princeton: Princeton UP, 1990. King, John N. ed., Voices Of The English Reformation: A Sourcebook.

Philadelphia: U of Pennsylvania P, 2004.

Leslie, Michael. Spenser's 'Fierce Warres and Faithfull Loves': Martial and chivalric Symbolism in The Faerie Queene. Cambridge: D.S. Brewer, 1983.

Levin, Richard A. "The Legende of the Redcrosse Knight and Una, or of the Love of a Good Woman." SEL: Studies in English Literature, 1500-1900, 31.1 (1991): 1-24.

Lewis, C.S. The Allegory of Love: A Study in Medieval Tradition. London: Oxford UP, 1936.

Spenser, Edmund. The Faerie Queen, edited by A.C. Hamilton et al. $2^{\text {nd }}$ ed. Harlow, England: Pearson Education, 2007.

Tolkien, J.R.R. "On Fairy-Stories.” In The Tolkien Reader. Introduction by Peter S. Beagle, 135-165. New York: Ballentine Books, 1966.

Waters, D. Douglas. "Prince Arthur as Christian Magnanimity in Book One of The Faerie Queene." Studies in English Literature, 1500-1900 9, no.1 (Winter 1969): 53-62.

Watkins, John. " 'And yet the end was not': Apocalyptic Deferral and Spenser's Literary Afterlife." In Worldmaking Spenser: Explorations in the Early Modern Age, edited by Patrick Cheney and Lauren Silberman, 156-173. Lexington: The UP of Kentucky, 2000.

Watkins, John. "Spenser's Poetry and the Apocalypse." In Early Modern English Poetry: A Critical Companion, edited by Patrick Cheney, Andrew Hadfield, and Garrett A. Sullivan Jr., 90-101. New York: Oxford UP, 2007.

Wofford, Suzanne L. "The Enfolding Dragon: Arthur and the Moral Economy of The Faerie Queene." In Edmund Spenser: Essays on Culture and Allegory, edited by Jennifer Klein Morrison and Matthew Greenfield, 135-165. Aldershot, England: Ashgate, 2000. 